\title{
FULL-LENGTH VP2 GENE ANALYSIS OF CANINE PARVOVIRUS REVEALS EMERGENCE OF NEWER VARIANTS IN INDIA
}

\author{
MANGADEVi NOOKALA ${ }^{1}$, HiRAK KUMAR MUKHOPADHYAY ${ }^{1 *}$, \\ AMSAVENI SIVAPRAKASAM ${ }^{1}$, BRINDHALAKSHMI BALASUBRAMANIAN ${ }^{1}$, \\ PRABHAKAR XAVIER ANTONY ${ }^{1}$, JACOB THANISLASS ${ }^{2}$, \\ Mouttou ViVeK SRINIVAS ${ }^{1}$ and RaghaVAN MadHUSOOdANAN PILlai ${ }^{1}$ \\ ${ }^{1}$ Department of Veterinary Microbiology, Rajiv Gandhi Institute of Veterinary Education \\ and Research, Puducherry, India \\ ${ }^{2}$ Department of Veterinary Biochemistry, Rajiv Gandhi Institute of Veterinary Education \\ and Research, Puducherry, India
}

(Received: 24 April 2016; accepted: 26 August 2016)

\begin{abstract}
The canine parvovirus (CPV) infection is a highly contagious and serious enteric disease of dogs with high fatality rate. The present study was taken up to characterize the full-length viral polypeptide 2 (VP2) gene of CPV of Indian origin along with the commercially available vaccines. The faecal samples from parvovirus suspected dogs were collected from various states of India for screening by PCR assay and $66.29 \%$ of samples were found positive. Six CPV-2a, three CPV-2b, and one CPV-2c types were identified by sequence analysis. Several unique and existing mutations have been noticed in CPV types analyzed indicating emergence of newer variants of CPV in India. The phylogenetic analysis revealed that all the field CPV types were grouped in different subclades within two main clades, but away from the commercial vaccine strains. CPV-2b and CPV-2c types with unique mutations were found to be establishing in India apart from the prevailing CPV-2a type. Mutations and the positive selection of the mutants were found to be the major mechanism of emergence and evolution of parvovirus. Therefore, the incorporation of local strain in the vaccine formulation may be considered for effective control of CPV infections in India.
\end{abstract}

Keywords: canine parvovirus (CPV), mutation, phylogenetic analysis, polymerase chain reaction (PCR), sequencing

\section{Introduction}

Canine parvovirus (CPV) infection is highly contagious and a serious enteric disease of dogs with high fatality rate. It is a member of the species

\footnotetext{
*Corresponding author; E-mail: mhirak@rediffmail.com
} 
Carnivore protoparvovirus 1, genus Protoparvovirus of the family Parvoviridae, which also includes feline panleukopenia virus (FPV) and mink enteritis virus. CPV caused by CPV-2 is considered as canine-specific variant of the FPV that emerged as a novel pathogen in the late 1970s as a consequence of an interspecies jump from other carnivores to dogs and spread rapidly worldwide [1]. However, by the end of 1980, CPV-2 was completely replaced globally in dogs by a genetic and antigenic variant termed CPV-2a with Met87Leu, Ile101Thr, Ala300Gly, Asp305Tyr, Asn375Asp, and Val555Ile variations [2]. Subsequently, viral polypeptide 2 (VP2) residue 426, changed from Asn426Asp and then from Asp426Glu in the so-called CPV-2b and CPV-2c antigenic variant strains, respectively. However, as the CPV-2b and CPV-2c antigenic strains differ from CPV-2a at only one position (VP2 residue 426), they are now considered to be variants of CPV2 a rather than distinct subtypes, as are all of the CPVs circulating worldwide today [3-13]. During early 1990s in German CPV isolates, an additional amino acid difference was observed in CPV-2a and CPV-2b at 297th amino acid position (Ser297Ala) and the mutants were designated as New CPV-2a/2b [14]. CPV and FPV are two closely related viruses, causing disease in respective hosts, but new variants of CPVs have acquired the feline host range allowing them to infect both cats and dogs [15-17], whereas the original CPV-2 does not replicate in cats.

Amplification of VP2 gene and subsequent sequencing of the PCR products, where many important informative amino acids lies would give definitive antigenic and genetic difference between the original CPV-2, its variants, and the vaccine strains [18]. As mutation and recombination in VP2 gene influence the host range and affinity of receptor binding [19], it becomes important to sequence full-length VP2 encoding gene for better and precise identification of emerging strains, their relationship with vaccine strains, and also to understand the evolutionary pattern of CPV strains in the field.

As no such study involving full-length VP2 encoding gene analysis had been documented with CPV isolates of Indian origin, the present study was undertaken for a detailed genetic analysis of full-length VP2 gene sequences of CPV types isolated from domestic dogs covering all the five geographical regions of India. The full-length VP2 encoding gene of the CPV types present in the commercial vaccines available in India were also analyzed.

\section{Materials and Methods}

Sample collection and laboratory processing

A total of 89 faecal samples/rectal swabs from CPV suspected diarrhoeic dogs of different age group were collected from different states covering all the 
five regions of India (Western, Eastern, Northern, Southern, and Central) over one year period (December 2013 to December 2014) as detailed in Table I. The faecal samples/rectal swabs were emulsified in $1 \mathrm{ml}$ of $0.1 \mathrm{M}$ PBS of $\mathrm{pH} 7.4$, stored at $4{ }^{\circ} \mathrm{C}$, and transported to the laboratory under refrigeration. The emulsions were centrifuged at $10,000 \mathrm{rpm}$ for $15 \mathrm{~min}$ at $4{ }^{\circ} \mathrm{C}$ and the supernatant was passed through $0.45 \mu \mathrm{m}$ membrane filter (Millipore, CA, USA). The filtrate was collected and stored at $-40{ }^{\circ} \mathrm{C}$ until further use.

\section{Screening of samples by polymerase chain reaction}

Total nucleic acid from all the clinical specimens was extracted by boilinglysis method at $96{ }^{\circ} \mathrm{C}$ for $10 \mathrm{~min}$ followed by chilling immediately in crushed ice. Following high speed centrifugation, the supernatants were diluted at 1:10 in milliQ water to reduce residual inhibitors of DNA polymerase activity $[18,20]$. The extracted template DNA was stored at $-40{ }^{\circ} \mathrm{C}$ until further use and was screened for the presence of CPV using $\mathrm{H}_{\text {for }} / \mathrm{H}_{\text {rev }}$ primer pair listed in Table II, which amplifies a $630 \mathrm{bp}$ fragment of the VP2 gene encoding capsid protein [21]. The DNA prepared from CPV-2 (Strain C154, Intervet India Pvt. Ltd., India)/ CPV-2b vaccine strain (Fort Dodge Animal Health Inc., USA) maintained in the Department of Veterinary Microbiology, Rajiv Gandhi Institute of Veterinary Education and Research, Puducherry, India, was used as positive control in the PCR assay.

The PCR-amplification of VP2 capsid protein gene was carried out using $100 \mathrm{ng}$ template DNA, $5 \mu \mathrm{l} 10 \times$ PCR buffer, $2 \mathrm{mM} \mathrm{MgCl}_{2}, 1 \mu \mathrm{l}$ of $10 \mathrm{mM}$ dNTPs, $10 \mu \mathrm{M}$ of forward and reverse primers, $2 \mathrm{U}$ of Taq DNA Polymerase (New England Biolabs, MA, USA) and the volume was made up to $50 \mu \mathrm{l}$ with Nuclease Free

Table I. Details of sample collection and the results

\begin{tabular}{|c|c|c|c|c|c|}
\hline S. No. & Regions & State/Union territory & Place & Clinical samples & Positive by PCR \\
\hline \multirow[t]{2}{*}{1.} & Western & Maharashtra & Mumbai & 5 & 3 \\
\hline & & & Nagpur & 14 & 10 \\
\hline \multirow[t]{2}{*}{2.} & Eastern & West Bengal & Kolkata & 15 & 9 \\
\hline & & Sikkim & Gangtok & 4 & 3 \\
\hline \multirow[t]{3}{*}{3.} & Northern & Punjab & Ludhiana & 9 & 8 \\
\hline & & & Gurdaspur & 9 & 4 \\
\hline & & Uttar Pradesh & Mathura & 9 & 5 \\
\hline \multirow[t]{2}{*}{4.} & Southern & Kerala & Thrissur & 7 & 4 \\
\hline & & Puducherry & Puducherry & 13 & 10 \\
\hline \multirow[t]{2}{*}{5.} & Central & Madhya Pradesh & Jabalpur & 4 & 3 \\
\hline & & Total & & 89 & $59(66.29 \%)$ \\
\hline
\end{tabular}




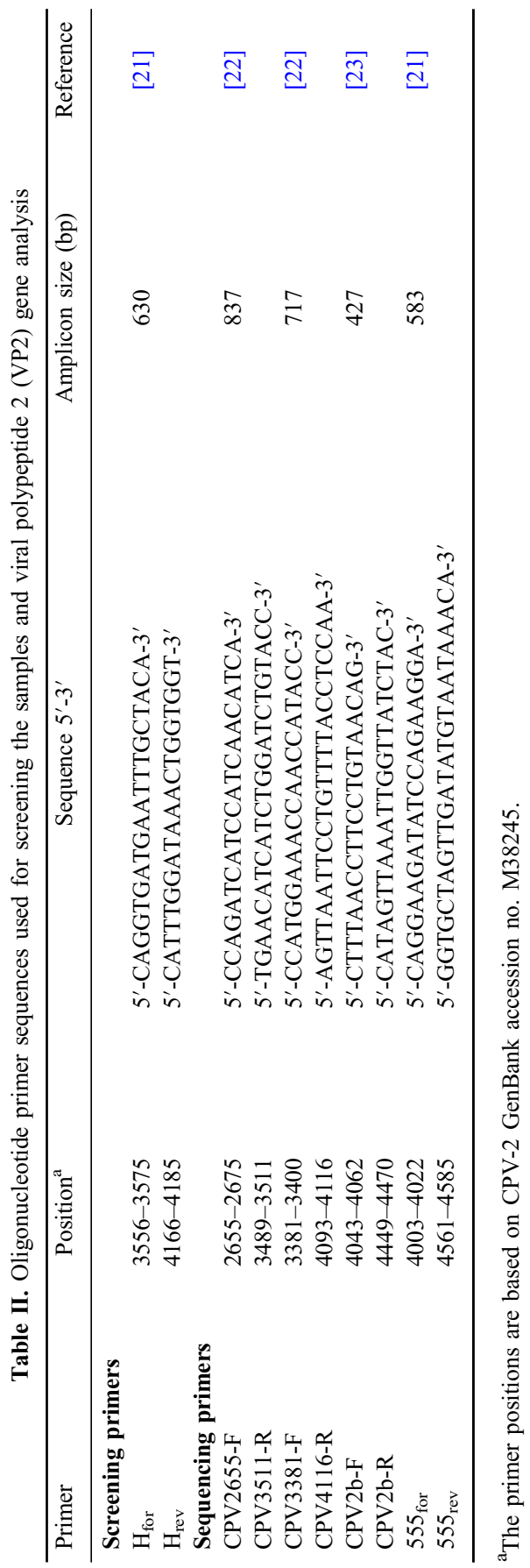


water. The PCR amplification consisted of initial denaturation at $95{ }^{\circ} \mathrm{C}$ for $5 \mathrm{~min}$ followed by 35 cycles of denaturation at $95^{\circ} \mathrm{C}$ for $30 \mathrm{~s}$, annealing at $55^{\circ} \mathrm{C}$ for $30 \mathrm{~s}$, and extension at $70^{\circ} \mathrm{C}$ for $1 \mathrm{~min}$, followed by a final extension at $70{ }^{\circ} \mathrm{C}$ for $10 \mathrm{~min}$. The PCR amplified products were resolved on $1.5 \%$ agarose gel containing ethidium bromide in Tris acetate EDTA (TAE) buffer and visualized under UV transilluminator (Syngene, UK).

\section{Virus isolation}

Virus isolation was carried out as per the procedure recommended by Hirayama et al. [24]. Twenty-four PCR positive samples representing the diverse geographical locations of India were randomly selected and subjected for isolation of virus in A-72 cell line maintained in RPMI-1640 media (Sigma-Aldrich, St. Louis, MO, USA). The clinical samples were filtered and used for virus isolation in A-72 cell line. The infected monolayers were harvested third day post inoculation (with or without cytopathic effect) by three cycles of alternative freezing, thawing, and stored at $-40^{\circ} \mathrm{C}$ until further use. After three blind passages in A-72 cell line, DNA released from the cell culture fluids were confirmed for the presence of the virus by PCR amplification using $\mathrm{H}_{\text {for }} / \mathrm{H}_{\text {rev }}$ primer pair.

\section{Genotyping of CPV samples/isolates}

Seven randomly selected PCR $\left(\mathrm{H}_{\mathrm{for}} / \mathrm{H}_{\mathrm{rev}}\right)$ positive clinical samples and three cell culture isolates were subjected to another four individual PCR assays using four sets of overlapping sequencing primer pairs listed in Table II following the same protocol as detailed earlier. The full-length VP2 gene of the CPV vaccine strains available in India was also amplified. The PCR-amplified products were excised from the gel and extracted using gel extraction kit (Qiagen, Hilden, Germany). The four overlapping PCR products of VP2 gene (for each sample/ isolate) were sequenced for both the strands of DNA $\left(5^{\prime}-3^{\prime}\right.$ and $\left.3^{\prime}-5^{\prime}\right)$ and aligned to determine their nucleotide/amino acid variations in VP2 gene. The sequencing was carried out using automated DNA sequencer (Applied Biosystems Inc., CA, USA) at Eurofins Genomics Private Limited, Bengaluru, India. The sequence chromatogram was visualized in BioEdit v 7.0.5 analysis software (Isis Therapeutics, Carlsbad, CA, USA). Nucleotide Blast was performed with the obtained sequences using the NCBI nucleotide database (http:/www.ncbi.nlm.nih.gov/ Blast) to confirm the genus specificity to CPV. VP2 gene sequences of FPV, CPV2, CPV-2a, CPV-2b, and CPV-2c from different part of the world were retrieved from the NCBI nucleotide database and multiple sequence alignment was 
performed using the Clustal $\mathrm{W}$ algorithm in MEGA5 software [25]. The aligned sequences of VP2 genes of 10 CPV types under this study were submitted in Genbank for allotment of accession numbers.

\section{Phylogenetic analysis}

The CPV sequences obtained in this study, the sequences of CPV-2/2b vaccine strains available in India and the sequences retrieved from GenBank were aligned and evolutionary history was inferred employing the maximum-likelihood method [26] based on the Tamura Nei parameter model implemented in MEGA 5 program. The branch lengths were measured in terms of the number of substitutions per site. Bootstrap test (1,000 replicates) was done to evaluate the confidence level of branching in the phylogenetic tree.

\section{Results}

Polymerase chain reaction

Of the total 89 faecal samples collected from CPV suspected dogs, 59 samples $(66.29 \%)$ were found positive for CPV by PCR assay (Table I). Higher incidence of CPV infection was observed in pups below six months of age $(74.58 \%)$.

\section{Virus isolation}

In A-72 cell culture, mild cytopathic effect in the form of rounding, increased granularity and detached cells could be seen 3-4 days post infection for 12 dog samples at third passage level. The cryolysates were also confirmed as positive for CPV by PCR. The virus in the remaining samples failed to grow in A-72 cell line.

\section{Sequencing and BLAST analysis}

Upon Basic Local Alignment Search Tool (BLAST) analysis, the specificity of the sequences of full-length VP2 gene of CPV obtained from 10 faecal samples/ cryolysates was found to be maximally identical (99-100\%) with VP2 gene sequences of CPV strains available in the GenBank. The sequencing results 
revealed six sequences obtained in this study (KLD3, MD1, SD2, WBD4, NAG3, and WBD1) as New CPV-2a, 3 sequences (KD4, KD5, and LD4) as New CPV-2b and 1 sequence (JD3) as CPV-2c (Supplementary Table I). The present study reports the isolation of CPV-2c in cell culture for the first time in India.

\section{Nucleotide sequence accession numbers and mutations}

The GenBank accession numbers for the CPV strains were depicted in Table III. Additionally, several non-synonymous (Table III) and synonymous (Supplementary Table II) mutations were also noticed in the CPV sequences analyzed in this study.

Phylogenetic analysis

All the CPV types sequenced in this study were distributed in three different monophyletic clades (Figure 1). All the six CPV-2a and interestingly the two CPV-2b types (KD4 and KD5, Kolkata) showed common ancestor with CPV-2a type from China (CPV-2a/CHINA/2011/JQ268283). Two CPV-2a types (KLD3, Thrissur and NAG3, Nagpur) showed immediate relationship with Uruguayan and Chinese CPV-2a isolates and the other four CPV-2a types (WBD1 and WBD4, Kolkata; MD1, Mumbai and SD2, Gangtok) showed independent evolution. The two CPV-2b types (KD4 and KD5, Kolkata) formed a separate subclade within the same CPV-2a clade and were related to a recent Chinese CPV-2b isolate (CPV-2b/ CHINA/2013/KR002799). However, the other CPV-2b type (LD4, Ludhiana) was arranged in a different clade (CPV-2b clade) and showed ancestral relationship with older CPV-2b types from USA (CPV-2b/USA/1998/EU659121 and CPV-2b/ USA/1998/AY742936). A commercial vaccine strain (CPV-2b) Duramune Max5 (Fort Dodge) also clustered in this group. The single CPV-2c type JD3 (Jabalpur) formed a different subclade in this clade and was ancestrally related to the CPV-2c isolates from Italy and Uruguay (CPV-2c/ITALY/2000/FJ222821 and CPV-2c/ URUGUAY/2011/KM457142). All the CPV-2 containing commercial vaccines like Vanguard (Pfizer), CaniShot K5 (Intas), Biocan (Bioveta), and Canigen (Virbac) were closely clustered in CPV-2 clade along with prototype CPV-2 strain (M38245) from USA.

\section{Discussion}

The result of the PCR screening assay in dogs was in concordance with the results obtained by Srinivas et al. [27] and Mukhopadhyay et al. [28]. 


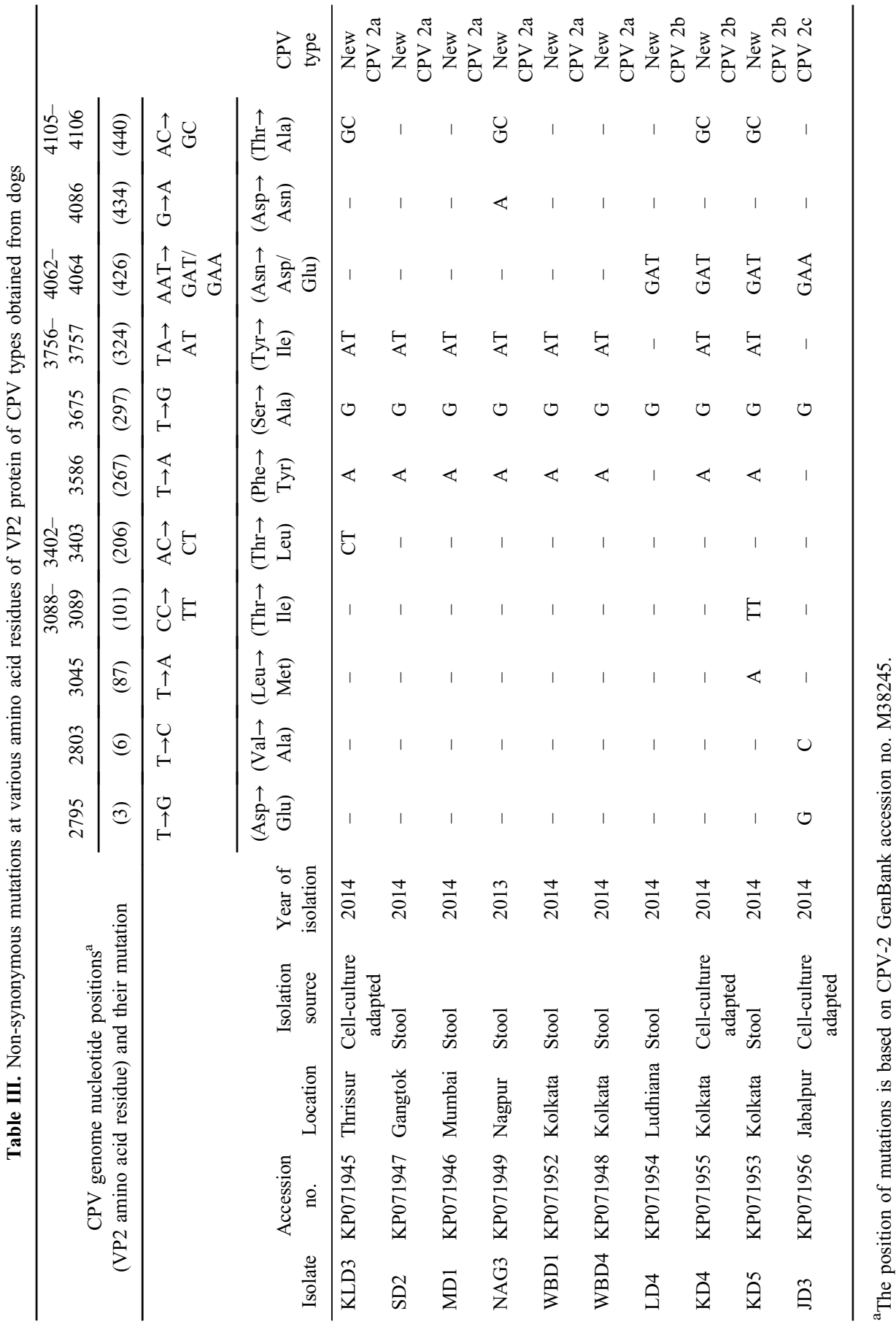




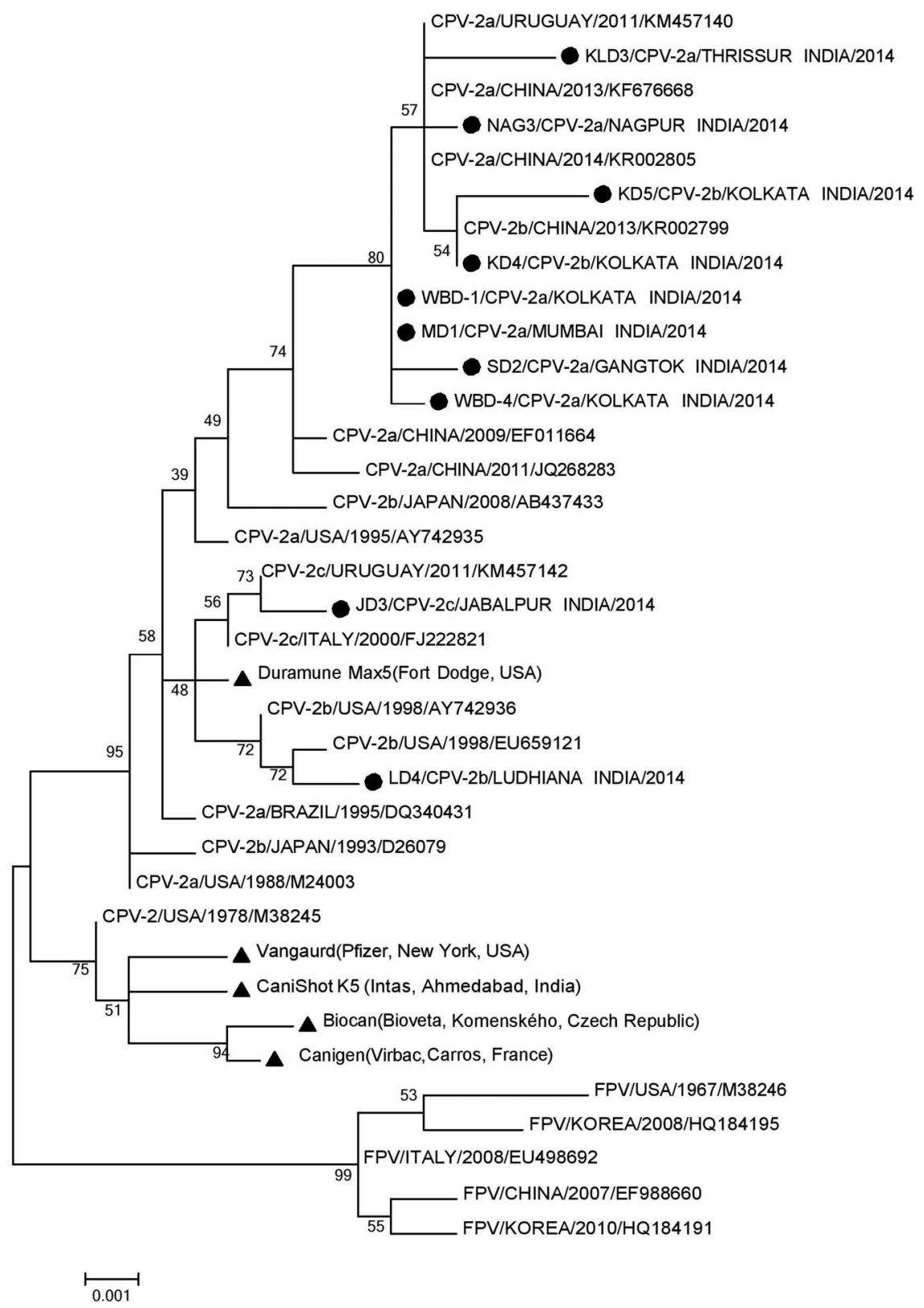

Figure 1. Maximum likelihood tree depicting phylogenetic relationship among CPV isolates. Parvoviruses obtained from dogs sequenced in this study are shown with solid circles and the vaccine strains are shown with solid triangles. Bootstrap values are shown next to the branches in the phylogenetic tree 
The disease was predominantly noticed in dogs between 0 - and 6-month age group $(74.58 \%)$ as also reported by other authors [29, 30]. It is well known that increased intestinal epithelial turnover caused by changes in the microflora, diet (weaning), and diminishing maternal antibody level are the predisposing factors to CPV infection in pups [31].

The present study, involving the full-length sequence analysis of VP2 gene for the first time in Indian CPV isolates, confirmed that the New CPV-2b type (Ala 297 \& Asp 426) had also established in diverse dog population in India along with the prevalent New CPV-2a type (Ala 297 and Asn 426). The presence of CPV-2c type in India was also identified and confirmed by the study. Nandi et al. [32] reported presence of CPV-2c type from North India, but it was not until 2015 (present study) that CPV-2c type was first isolated in India (Jabalpur, Madhya Pradesh, and Central India), which clearly indicated slow but steady spread of $\mathrm{CPV}-2 \mathrm{c}$ type in Indian dog population. It is a matter of concern as CPV-2c type is often associated with severe infections even in adult dogs regardless of their vaccination status [33] and replaces the other predominant CPV types within few years of its emergence [34-36].

Two unique amino acid changes Asp3Glu caused by a $T \rightarrow G$ transversion in the third nucleotide of the corresponding codon (nt 9 of the VP2 gene) and Val6Ala caused by a $\mathrm{T} \rightarrow \mathrm{C}$ transition in the second nucleotide of the corresponding codon (nt 17 of the VP2 gene) were noticed in the CPV-2c (JD3) type isolated in the present study. These mutations were also never reported in any other CPV-2c types sequenced to date. Very recently, Wang et al. [37] reported isolation of a novel Ala5Gly mutant of CPV-2c types in China. Although the functional impact of these mutations was yet to be ascertained, the present study, however, confirmed that this particular stretch of the VP2 gene of CPV-2c type was in the midst of an active evolution process in India and China.

In KD5, a CPV-2b type from Kolkata, two interesting and unique amino acid changes Leu87Met (caused by a $\mathrm{T} \rightarrow \mathrm{A}$ transversion in the first nucleotide of the corresponding codon; nt 259 of the VP2 gene) and Thr101Ile (caused by a $\mathrm{CC} \rightarrow \mathrm{TT}$ double transition in the second and third nucleotide of the corresponding codon; nt 302 and 303 of the VP2 gene) were identified. Four amino acid changes at $87,101,300$, and 305 positions of VP2 residues differentiate the CPV-2a type and its variants from the prototype CPV-2. Mutations at these four amino acid positions influence infection by altering binding to the canine transferrin receptor (TfR), the host cell attachment protein. Additionally, these four mutations have been shown to alter antibody binding, as they cluster to a position on the capsid surface where an antigenic site overlaps with receptor binding site. Therefore, this CPV-2b type (KD5), showing mutations in two (87 and 101) out of the four 
differentiating amino acids might be either mutating back to CPV-2 or in a process of recombination between the vaccine strain (containing CPV-2 strain) and the field strain. Mochizuki et al. [38] provided the first documentation of clear evidence of recombination events between CPV-2 (Vaccine) and CPV-2a/ $\mathrm{CPV}-2 \mathrm{~b}$ field viruses in dogs vaccinated with live combined vaccine containing CPV-2.

Among the other non-synonymous mutations, the amino acid change Phe267Tyr was observed in all the six CPV-2a types (KLD3, SD2, MD1, NAG3, WBD1, and WBD4) and the two CPV-2b types (KD4 and KD5) of dogs. This mutation was also reported previously in CPV-2a and CPV-2b types [28, 39-41]. The amino acid residue 267 is not exposed on the capsid surface and substitutions in this position may not affect the antigenicity of the virus [42]. All the CPV types analyzed in this study also showed amino acid change Ser297Ala, which was under strong positive selection pressure and played important role in host cell adaption $[43,44]$.

Similarly the amino acid change Tyr324Ile was noticed in most of the sequences analyzed in this study. Similar codon changes at amino acid positions 324 were also reported in the CPVs isolated in different countries [28, 41, 44-46]. Horiuchi et al. [47] revealed that the residue 324 was prone to strong positive selection in all carnivorous CPV isolates. The residue 324 was adjacent to residue 323, responsible for TfR binding, and together with residue 93, determined the canine host range. Therefore, mutation at amino acid residue 324 is likely to have an impact on the parvovirus host range. It was also documented that Ile-324 substitution was in regions of potentially important antigenic epitopes and this substitution might have a direct influence on viral biology [48]. Interestingly, the frequency of CPVs carrying mutations at 267Tyr and 324Ile residues had increased enormously and had reached a high prevalence among Indian CPV isolates only since 2012-13 [27, 28, 44].

The next important amino acid change Thr440Ala was observed in two CPV-2a types (KLD3 and NAG3) and two CPV-2b types (KD4 and KD5). The amino acid residue 440 is important because it is located at the top of the 3 -fold spike (GH loop) of the VP2 protein on the surface of the capsid, the main antigenic site of the virus $[49,50]$. This residue was undergoing positive selection for the past few years and had evolved independently in different populations, which explained its world-wide mutation in unrelated CPV-2 populations [51]. Similar codon change at amino acid position 440 was also reported in CPVs isolated in different countries [28, 44, 52]. Mutation at amino acid residue 440 would, therefore, result in emergence of further antigenic variants. Decaro et al. [53] reported an Asp434Val mutation in certain Italian CPV types; but in the present study, a CPV-2a type (NAG3) isolated from Nagpur showed a different mutation 
in the same amino acid residue (Asp434Asn). In addition, 14 synonymous substitutions were also observed in the sequences under study.

No indication of separation of lineage based on geographical location could be identified in the phylogenetic study and most CPV types were found to have evolved independently. The interesting clustering of two CPV-2b (KD4 and KD5) types along with recently isolated Chinese CPV-2b strains (KR002799) in the CPV-2a clade provides ample proof of continuous evolution of CPVs. The commercially available vaccine strains (CPV-2) were clustered in CPV-2 clade away from most of the CPV field types sequenced in this study. In fact, Indian CPVs in the field are moving away from the commercial vaccine strains as is evident from the phylogenetic tree.

Therefore, as per the present study, mutations and the positive selection of the mutants was found to be the major mechanism of continuous emergence and the evolution of CPVs in India. This study involving full-length analysis of VP2 gene, therefore, definitely added valuable information to the evolution of CPVs in India. CPV-2a and CPV-2b variants have established in different geographical regions of India and CPV-2c also is in the process of establishing in the field. Constant monitoring and surveillance of larger areas to identify and analyze newer CPV types and variants has to be continued. Vaccination with the conventional CPV-2 based vaccines result in evolutionary pressure on the field viruses leading to emergence of newer strains/variants. These newer strains/ variants can spread in immunized dogs by breaking through the vaccine induced defence especially in passively immune new born pups. Therefore, time has come to have a close look on CPV vaccine policy in India and considering the current epidemiological scenario, incorporation of prevailing local strains may be the need of the hour.

\section{Acknowledgements}

The grant received from DBT, Government of India (BT/PR14677/ADV/ $57 / 111 / 2010$ ) to carry out the project is highly acknowledged. The authors are also thankful to Dean, Rajiv Gandhi Institute of Veterinary Education and Research, Puducherry, India, for providing necessary funds and facilities to carry out this study. Mangadevi Nookala and Hirak Kumar Mukhopadhyay contributed equally to the study.

\section{Conflict of Interest}

The authors declare no conflict of interest. 


\section{References}

1. Parrish, C. R., O'Connell, P. H., Evermann, J. F., Carmichael, L. E.: Natural variation of canine parvovirus. Science 230, 1046-1048 (1985).

2. Parrish, C. R., Aquadro, C. F., Carmichael, L. E.: Canine host range and a specific epitope map along with variant sequences in the capsid protein gene of canine parvovirus and related feline, mink, and raccoon parvoviruses. Virology 166, 293-307 (1988).

3. Organtini, L. J., Allison, A. B., Lukk, T., Parrish, C. R., Hafenstein, S.: Global displacement of canine parvovirus by a host-adapted variant: Structural comparison between pandemic viruses with distinct host ranges. J Virol 89, 9-12 (2015).

4. Filipov, C., Desario, C., Patouchas, O., Eftimov, P., Gruichev, G., Manov, V., Filipov, G., Buonavoglia, C., Decaro, N.: A ten-year molecular survey on parvoviruses infecting carnivores in Bulgaria. Transbound Emerg Dis 63, 460-464 (2014).

5. Cavalli, A., Desario, C., Kusi, I., Mari, V., Lorusso, E., Cirone, F., Kumbe, I., Colaianni, M. L., Buonavoglia, D., Decaro, N.: Detection and genetic characterization of Canine parvovirus and Canine coronavirus strains circulating in district of Tirana in Albania. J Vet Diagn Invest 26, 563-566 (2014).

6. Decaro, N., Desario, C., Amorisco, F., Losurdo, M., Elia, G., Parisi, A., Ventrella, G., Martella, V., Buonavoglia, C.: Detection of a canine parvovirus type 2c with a noncoding mutation and its implications for molecular characterisation. Vet J 196, 555-557 (2013).

7. McElligott, S., Collins, P. J., Sleator, R. D., Martella, V., Decaro, N., Buonavoglia, C., O'shea, H.: Detection and genetic characterization of canine parvoviruses and coronaviruses in southern Ireland. Arch Virol 156, 495-503 (2011).

8. Ntafis, V., Xylouri, E., Kalli, I., Desario, C., Mari, V., Decaro, N., Buonavoglia, C.: Characterization of Canine parvovirus 2 variants circulating in Greece. J Vet Diagn Invest 22, 737-740 (2010).

9. Decaro, N., Desario, C., Billi, M., Mari, V., Elia, G., Cavalli, A., Martella, V., Buonavoglia, C.: Western European epidemiological survey for parvovirus and coronavirus infections in dogs. Vet J 187, 195-199 (2011).

10. Touihri, L., Bouzid, I., Daoud, R., Desario, C., El Goulli, A. F., Decaro, N., Ghorbel, A., Buonavoglia, C., Bahloul, C.: Molecular characterization of canine parvovirus-2 variants circulating in Tunisia. Virus Genes 38, 249-258 (2009).

11. João-Vieira, M., Silva, E., Oliveira, J., Luísa-Vieira, A., Decaro, N., Desario, C., Muller, A., Carvalheira, J., Buonavoglia, C., Thompson, G.: Canine parvovirus 2c infection in central Portugal. J Vet Diagn Invest 20, 488-491 (2008).

12. Decaro, N., Desario, C., Addie, D. D., Martella, V., Vieira, M. J., Elia, G., Zicola, A., Davis, C., Thompson, G., Thiry, E., Truyen, U., Buonavoglia, C.: The study molecular epidemiology of canine parvovirus, Europe. Emerg Infect Dis 13, 1222-1224 (2007).

13. Hong, C., Decaro, N., Desario, C., Tanner, P., Pardo, M. C., Sanchez, S., Buonavoglia, C., Saliki, J. T.: Occurrence of canine parvovirus type $2 \mathrm{c}$ in the United States. J Vet Diagn Invest 19, 535-539 (2007).

14. Martella, V., Cavalli, A., Decaro, N., Elia, G., Desario, C., Campolo, M., Bozzo, G., Tarsitano, E., Buonavoglia, C.: Immunogenicity of an intranasal administered modified live canine parvovirus type $2 \mathrm{~b}$ vaccine in pups with maternally derived antibodies. Clin Diagn Lab Immunol 12, 1243-1245 (2005). 
15. Clegg, S. R., Coyne, K. P., Dawson, S., Spibey, N., Gaskell, R. M., Radford, A. D.: Canine parvovirus in asymptomatic feline carriers. Vet Microbiol 157, 78-85 (2012).

16. Decaro, N., Desario, C., Amorisco, F., Losurdo, M., Colaianni, M. L., Greco, M. F., Buonavoglia, C.: Canine parvovirus type $2 \mathrm{c}$ infection in a kitten associated with intracranial abscess and convulsions. J Feline Med Surg 13, 231-236 (2011).

17. Decaro, N., Buonavoglia, D., Desario, C., Amorisco, F., Colaianni, M. L., Parisi, A., Terio, V., Elia, G., Lucente, M. S., Cavalli, A., Martella, V., Buonavoglia, C.: Characterisation of canine parvovirus strains isolated from cats with feline panleukopenia. Res Vet Sci 89, 275278 (2010).

18. Decaro, N., Elia, G., Desario, C., Roperto, S., Martella, V., Campolo, M., Lorusso, A., Cavalli, A., Buonavoglia, C.: A minor groove binder probe real-time PCR assay for discrimination between type 2-based vaccines and field strains of canine parvovirus. J Virol Methods 136, 65-70 (2006).

19. Parrish, C. R., Aquadro, C. F., Strassheim, M. L., Evermann, J. F., Sgro, J. Y., Mohammed, H. O.: Rapid antigenic-type replacement and DNA sequence evolution of canine parvovirus. J Virol 65, 6544-6552 (1991).

20. Mukhopadhyay, H. K., Amsaveni, S., Matta, S. L., Antony, P. X., Thanislass, J., Pillai, M.: Development and evaluation of loop-mediated isothermal thermal amplification for rapid and sensitive detection of canine parvovirus DNA directly in faecal specimens. Lett Appl Microbiol 55, 202-209 (2012).

21. Buonavoglia, C., Martella, A., Pratella, M., Tempesta, A., Cavalli, D., Buonavoglia, G., Bozzo, G., Decaro, N., Carmichael, L. E.: Evidence for evolution of canine parvovirus type-2 in Italy. J Gen Virol 82, 3021-3025 (2001).

22. Decaro, N., Desario, C., Lucente, M. S., Amorisco, F., Campolo, M., Elia, G., Cavalli, A., Martella, V., Buonavoglia, C.: Specific identification of feline panleukopenia virus and its rapid differentiation from canine parvoviruses using minor groove binder probes. J Virol Methods 147, 67-71 (2008).

23. Pereira, C. A., Monezi, T. A., Mehnert, D. U., D’Angelo, M., Durigon, E. L.: Molecular characterization of canine parvovirus in Brazil by polymerase chain reaction assay. Vet Microbiol 75, 127-133 (2000).

24. Hirayama, K., Kano, R., Kanai, T. H., Tuchiya, K., Tsuyama, S., Nakamura, Y., Sasaki, Y., Hasegawa, A.: $\mathrm{VP}_{2}$ gene of a canine parvovirus isolate from stool of a puppy. J Vet Med Sci 67, 139-143 (2005).

25. Tamura, K., Peterson, D., Peterson, N., Stecher, G., Nei, M., Kumar, S.: MEGA5: Molecular evolutionary genetics using maximum likelihood, evolutionary distance, and maximum parsimony methods. Mol Biol Evol 28, 2731-2739 (2011).

26. Felsenstein, J.: Confidence limits on phylogenies: An approach using the bootstrap. Evolution 39, 783-791 (1985).

27. Srinivas, V. M. V., Mukhopadhyay, H. K., Thanislass, J., Antony, P. X., Pillai, R. M.: Molecular epidemiology of canine parvovirus in southern India. Vet World 6, 744-749 (2013).

28. Mukhopadhyay, H. K., Matta, S. L., Amsaveni, S., Antony, P. X., Thanislass, J., Pillai, R. M.: Phylogenetic analysis of canine parvovirus partial $\mathrm{VP}_{2}$ gene in India. Virus Genes 48, 89-95 (2014).

29. Houston, D. M., Ribble, C. S., Head, L. L.: Risk factors associated with parvovirus enteritis in dogs: 283 cases (1982-1991). J Am Vet Med Assoc 208, 542-546 (1996). 
30. Mohanraj, J., Mukhopadhyay, H. K., Thanislass, J., Antony, P. X., Pillai, R. M.: Isolation, molecular characterization and phylogenetic analysis of canine parvovirus. Infect Genet Evol 10, 1237-1241 (2010).

31. Decaro, N., Desario, C., Campolo, C., Cavalli, A., Ricci, D., Martella, V., Tempesta, M., Buonavoglia, C.: Evaluation of lactogenic immunity to canine parvovirus in pups. New Microbiol 27, 375-379 (2004).

32. Nandi, S., Chidri, S., Kumar, M., Chauhan, R. S.: Occurrence of canine parvovirus type 2c in the dogs with haemorrhagic enteritis in India. Res Vet Sci 88, 169-171 (2010).

33. Decaro, N., Buonavoglia, C.: Canine parvovirus - A review of epidemiological and diagnostic aspects, with emphasis on type 2c. Vet Microbiol 155, 1-12 (2012).

34. Calderon, M. G., Romanutti, C., D’Antuono, A., Keller, L., Mattion, N., La Torre, J.: Evolution of canine parvovirus in Argentina between years 2003 and 2010: CPV2c has become the predominant variant affecting the domestic dog population. Virus Res 157, 106-110 (2011).

35. Aldaz, J., Diaz, J. G., Calleros, L., Sosa, K., Iraola, G., Marandino, A., Hernández, M., Panzera, Y., Pérez, R.: High local genetic diversity of canine parvovirus from Ecuador. Vet Microbiol 166, 214-219 (2013).

36. Miranda, C., Parrish, C. R., Thompson, G.: Epidemiological evolution of canine parvovirus in the Portuguese domestic dog population. Vet Microbiol 183, 37-42 (2016).

37. Wang, J., Cheng, S., Yi, L., Cheng, Y., Yang, S., Xu, H., Zhao, H., Yan, X., Wu, H.: Evidence for natural recombination between mink enteritis virus and canine parvovirus. Virol J 9, 252 (2012).

38. Mochizuki, M., Ohshima, T., Une, Y., Yachi, A.: Recombination between vaccine and field strains of canine parvovirus is revealed by isolation of virus in canine and feline cell cultures. J Vet Med Sci 70, 1305-1314 (2008).

39. Nakamura, M., Tohya, Y., Miyazawa, T., Mochizuki, M., Phung, H. T., Nguyen, N. H., Huynh, L. M., Nguyen, L. T., Nguyen, P. V., Nguyen, N. P., Akashi, H.: A novel antigenic variant of canine parvovirus from a Vietnamese dog. Arch Virol 149, 2261-2269 (2004).

40. Phromnoi, S., Sirinarumitru, K., Sirinarumitru, T.: Sequence analysis of $\mathrm{VP}_{2}$ gene of canine parvovirus isolates in Thailand. Virus Genes 41, 23-29 (2010).

41. Zhang, R., Yang, S., Zhang, W., Zhang, T., Xie, Z., Feng, H., Wang, S., Xia, X.: Phylogenetic analysis of the $\mathrm{VP}_{2}$ gene of canine parvoviruses circulating in China. Virus Genes 40, 397-402 (2010).

42. Agbandje, M. C., Parrish, C. R., Rossman, M. G.: The recognition of parvovirus capsids by antibodies. Semin Virol 6, 219-231 (1995).

43. Pereira, C. A., Leal, E. S., Durigon, E. L.: Selective regimen shift and demographic growth increase associated with the emergence of high fitness variants of canine parvovirus. Infect Genet Evol 7, 399-409 (2007).

44. Mittal, M., Chakravarti, S., Mohapatra, J. K., Chug, P. K., Dubey, R., Upmanuyu, V., Narwal, P. S., Kumar, A., Churamani, C. P., Kanwar, N. S.: Molecular typing of canine parvovirus strains circulating from 2008 to 2012 in an organized kennel in India reveals the possibility of vaccination failure. Infect Genet Evol 23, 1-6 (2014).

45. Dogonyaro, B. B., Bosman, A. M., Sibeko, K. P., Venter, E. H., Vuuren, V. M.: Genetic analysis of the $\mathrm{VP}_{2}$ gene of canine parvovirus strains from Africa. Vet Microbiol 165, 460465 (2013). 
46. Csagola, A., Varga, S., Lorincz, M., Tuboly, T.: Analysis of the full length $\mathrm{VP}_{2}$ protein of canine parvoviruses circulating in Hungary. Arch Virol 159, 2441-2444 (2014).

47. Horiuchi, M., Goto, H., Ishiguro, N., Shinagawa, M.: Mapping of determinants of the host range of canine cells in the genome of canine parvovirus/mink enteritis virus chimeric virus. J Gen Virol 75, 1319-1328 (1994).

48. Hueffer, K., Parker, J. S., Weichert, W. S., Geisel, R. E., Sgro, J. Y., Parrish, C. R.: The natural host range shift and subsequent evolution of canine parvovirus resulted from virusspecific binding to the canine transferrin receptor. J Virol 77, 1718-1726 (2003).

49. Battilani, M., Ciulli, S., Tisato, E., Prosperi, S.: Genetic analysis of canine parvovirus isolates (CPV-2) from dogs in Italy. Virus Res 83, 149-157 (2002).

50. Tsao, J., Chapman, M. S., Agbandje, M., Keller, W., Smith, K., Luo, M., Smith, T. J., Rossmann, M. G., Compans, R. W., Parrish, C. R.: The three dimensional structure of canine parvovirus and its functional implications. Science 251, 1456-1464 (2008).

51. Decaro, N., Desario, C., Elia, G., Campolo, M., Lorusso, A., Mari, U., Martella, V., Buonavoglia, C.: Occurrence of severe gastroenteritis in pups after canine parvovirus vaccine administration: A clinical and laboratory diagnostic dilemma. Vaccines 25, 1161-1166 (2007).

52. Castro, T. X., Costa, E. M., Leite, J. P., Labarthe, N. V., Garcia, R. C. N. C.: Partial VP 2 sequencing of canine parvovirus (CPV) strains circulating in the state of Rio de Janerio, Brazil: Detection of the new variant CPV-2c. Braz J Microbiol 41, 1093-1098 (2010).

53. Decaro, N., Desario, C., Parisi, A., Martella, V., Lorusso, A., Miccolupo, A., Mari, V., Colaianni, M. L., Cavalli, A., Di-Trani, L., Buonavoglia, C.: Genetic analysis of canine parvovirus type 2c. Virology 385, 5-10 (2009). 